D-dimerモノクローナル抗体による安定化

フィブリン分解産物測定の臨床的意義

\author{
中川 雅夫* 辻肇* 宇野 雅史* 豊田 武夫* \\ 沢田 昌平* 白井 馨* 小林 恭一郎* \\ 高淵 洋彰* 渡辺 雅彦*
}

\title{
Clinical significance of the measurement of crosslinked fibrin derivatives with monoclonal antibody
}

\author{
Masao NAKAGAWA*, Hajime TSUJI,* Masashi UNO*, Takeo TOYODA*, \\ Shohei SAWADA*, Kaoru SHIRAI*, Kyoichiro KOBAYASHI*, \\ Hiroaki TAKABUCHI* and Masahiko WATANABE*
}

Key words : crosslinked fibrin degradation products, DIC, anti D-dimer monoclonal antibody, ELISA, Latex agglutination assay

Plasma levels of crosslinked fibrin degradation products(XDP)in 500 healthy subjects (250 male and 250 female), 18 patients with disseminated intravascular coagulation (DIC) and patients with thrombotic disease were measured by the enzyme linked immunosorbent assay (ELISA) using specific anti D-dimer monoclonal antibody.

Plasma levels of XDP in 500 healthy subjects were $174(38 \sim 309) \mathrm{ng} / \mathrm{m} l$ and sex related change was observed $(\mathrm{p}<0.01)$. High XDP values were observed in all of 18 patients with DIC. The results were also well correlated with those obtained by the latex agglutination assay.

These results indicate that the measurement of XDP using anti D-dimer monoclonal antibody could be one of the sensitive parameters in thrombotic and fibrinolytic condition especially DIC.

* 京都府立医科大学 第二内科学教室〔テ 602 京都市上京区河原町通広小路上ル梶井町〕; Second Department of Medicine, Kyoto Prefectural University of Medicine, Kyoto, Japan. 受付 : 1988. 9. 10. 受理 : 1989. 1. 7 . 


\section{はじめに}

DIC をはじめ種々の血栓性疾患など血液凝 固の亢進状態が存在する場合には生体の恒常性 の維持機構の作動により線維素溶解現象も六進 するととが知られている。しかしながら線溶療 法時などにみられる一次線溶の亢進の結果産生 されるフィブリノゲン分解産物と DIC のでと く一旦形成された血栓の溶解（二次線溶）に上 り生じる安定化フィブリンからのフィブリン分 解産物との鑑別はその病態を検索する上で重要 である。乙の度，酵素免疫测定法によるDdimer 測定キットを用い，健常者ならびに各種 血栓性疾患々者の血漿につき若干の検討を行っ たので報告する．

\section{I. 試料および方法}

\section{A 検 体}

健常成人 500 名（男性 250 名, 女性 250 名, 平均年齢 $34.8 \pm 12.5$ 歳）ならびに各種血栓性 疾患々者 57 名から静脈採血を行い $3.8 \%$ クエ ン酸ナトリウム加血漿を得てこれを試料とし た。

\section{B D-dimer 測定法}

i) Asserachrom D-Di 法 (Stago 社):

マイクロタイタープレートのウェルに抗 Ddimer マウスモノクローナル抗体液 $200 \mu l$ を 添加し室温で一晚コーティングし, 洗浄後希釈 した添付標準品および検体 $200 \mu l$ を加えて室 温にて一時間反応させた. 洗浄後ペルオキシダ 一ゼ標識抗 FDP-D 分画抗体液 $200 \mu l$ を加え て同様に反応させ，基質としてオルトフェニレ ンジアミン液 $200 \mu l$ で発色させ， $3 \mathrm{M}$ 硫酸 50 $\mu l$ で反応を停止させ，光電比色計を用い波長 は $492 \mathrm{~nm}$ にて吸光度を測定した。なお測定值 はフィブリノゲン換算量にて表現した.

ii）Dダイマー測定用.試薬「BMY」[D-Di Test 法] (Stago 社, ベーリンガー・マンハイ ム山之内）:

D-dimer 分画に対して得られたモノクロー ナル抗体をコーティングしてあるラテックス試 薬 $20 \mu l$ を黒背景のスライドガラス上に滴下 し，検体 $20 \mu l$ を加えて覺拌し， 2 分後に凝集
の有無を肉眼的に判定した。 このとき添付の陽 性コントロールと緩衝液（陰性）を同時に測定 して参考とした，通常フィブリノゲン量に換算 して $0.5 \mu \mathrm{g} / \mathrm{ml}$ 以上に相当する D-dimer 分 画が含まれている場合には陽性の凝集像を示 し，その場合にはさらに検体を緩衝液で希釈し て測定を行った。

\section{C 統計処理}

健常者成人の測定結果に基づく各年齿首別の 正常值の決定には確率紙法を用いた反復切断法 により統計処理を行った。

\section{II. 検 討 結 果}

\section{A. 健常成人における D-dimer 值 \\ i) Asserachrom D-Di}

健常人 500 例の D-dimer 值のヒストグラム を図 1 に示す。ヒストグラムは対数正規分布 を示し，その平均值（信頼限界）は 174 (38〜 309) $\mathrm{ng} / \mathrm{ml}$ であった。 又, 性別の平均值は男 性 147 (32 263) $\mathrm{ng} / \mathrm{ml}$, 女性 198 (49 347) $\mathrm{ng} / \mathrm{m} l$ であり男女間に危険率 $1 \%$ 以下で有意 な差が認められた（図 2).

更に，加榆とともに D-dimer 值が高值を示 す傾向があった（図 3).

ii) D-Di Test

健常人 500 例の D-Dimer 值のヒストグラ ムを図 4 に示す。平均值は, $0.5 \mu \mathrm{g} / \mathrm{m} l$ 以下 であった。

B。各種疾患における D-dimer 值 i) $\mathrm{DIC}$

DIC 症例 18 例における Asserachrom DDi の值は $650 \sim 16,000 \mathrm{ng} / \mathrm{m} l$ と全例異常を示 し，汃広範囲に分布していた（図 5).

D-Di Test では 18 例中 13 例が $1 \mu \mathrm{g} / \mathrm{m} l$ 以上であった（図 6).

敗血症に DIC を合併した症例 1（図 7）及 び肺癌に DIC を合併した症例 2（図 8）にお いて D-dimer の測定值は，Latex 法による D-dimer の測定值あるいは従来法による FDP の測定值の変動と平行した増減を示し，また臨 床経過とも良好な相関を示した。

ii）他の血栓性疾患

白血病, 肝癌, 肺癌などの悪性腫瘍性疾患, 


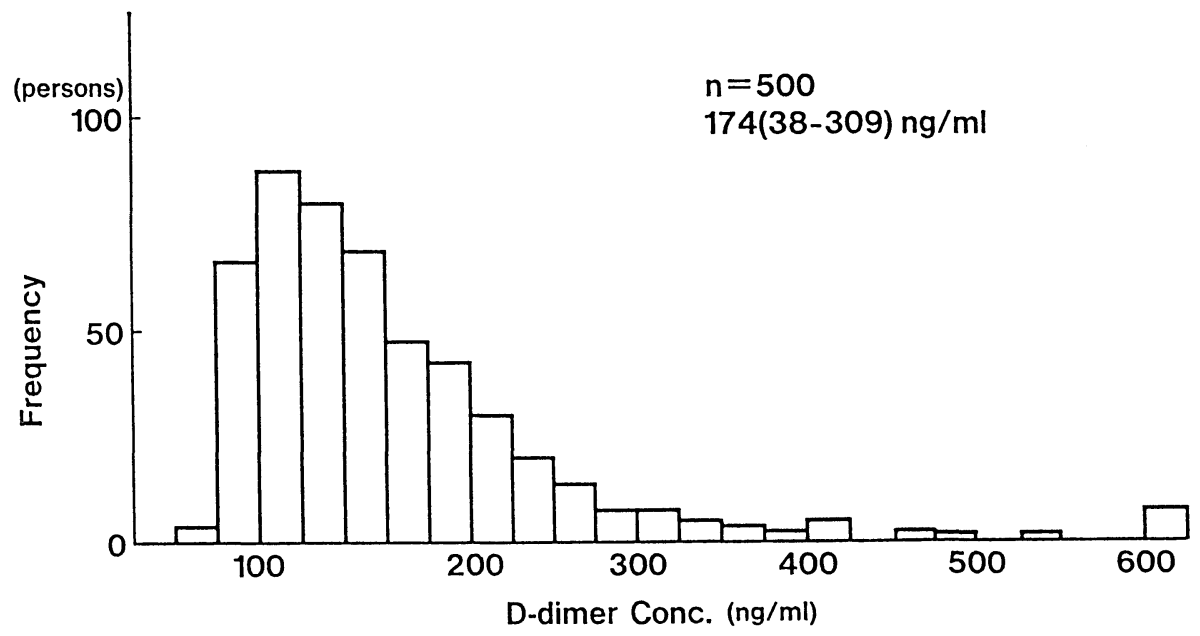

Fig. 1 Histogram of normal subjects with Asserachrom D-Di

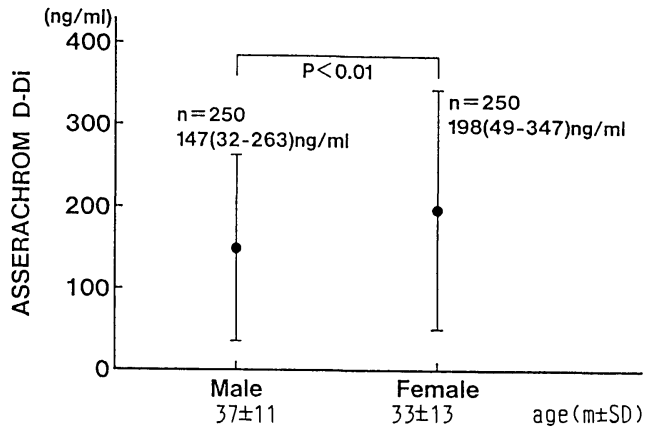

Fig. 2 Sex related change in the plasma D-dimer levels with Asserachrom D-Di

敗血症などで高值を示したが，良好なコントロ ール状態にある糖尿病では正常值を示した（困 5 , 困 6).

\section{III. 考察}

凝固機序の作動時には生体の homeostasis の維持のために線溶機序も同時に作動すること が知られており線溶機序と凝固機序の相互関係 を同時に把握するととが重要である，最近この 目的にしたがって，種々の検討がなされてきた が，最も新しい検索法として注目されているの は，凝固・線溶機序の作動により産生される凝 固線溶因子の分解産物の測定 ${ }^{1) ~ 3 ~}$ あるいは凝 固・線溶系機序の活性化の結果として産生され る活性化凝固因子あるいは活性化線溶因子亡こ
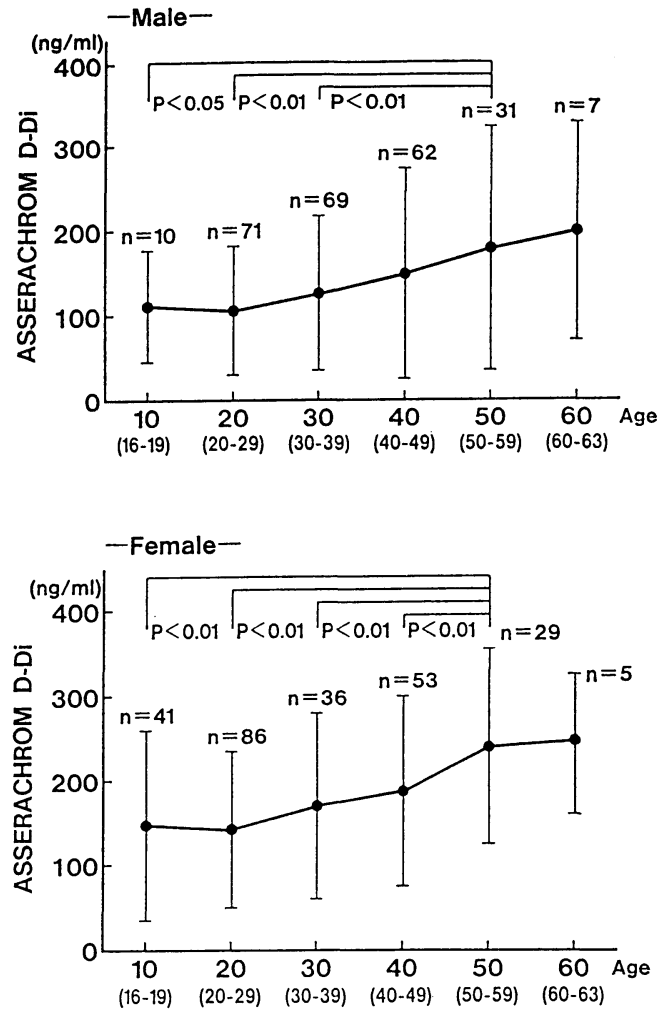

Fig. 3 Age related change in plasma Ddimer levels with Asserachrom D$\mathrm{Di}$

れらの阻止因子の複合体の検出法である。しか し Thrombin-AT III複合体 (TAT) あるいは Plasmin-Plasmin inhibitor 複合体 (PIC) の ELISA による検出法以外には複合体の測定に 


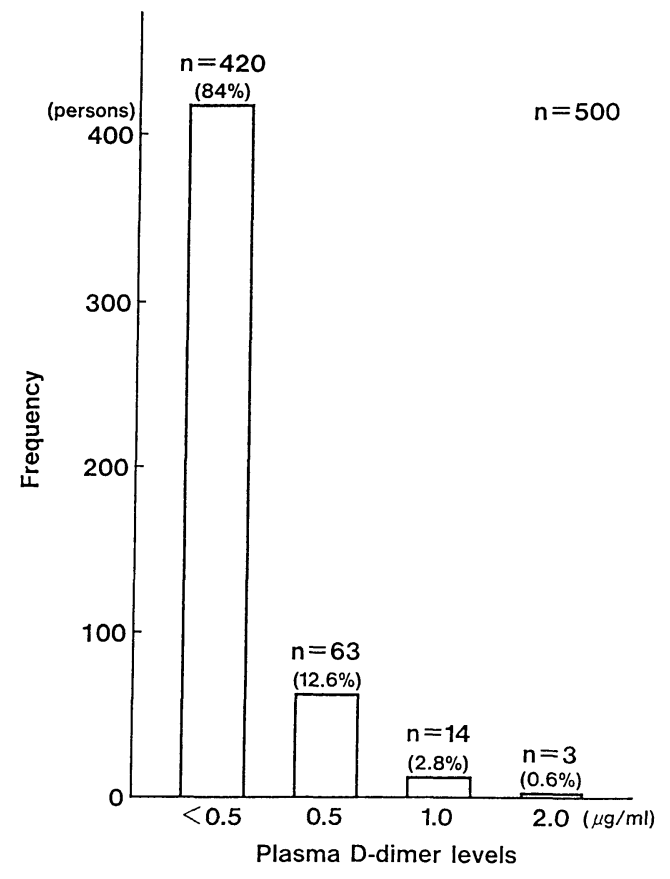

Fig. 4 Histogram of normal subjects with D-Di Test
関しては実用化にはなお困難な問題が残されて いる.

分子生物学的研究の進歩によりモノクローナ ル抗体の作成が容易に行われるようになりこの 成果が臨床に応用されようとしている，FDP の測定は DIC などの血液凝固・線溶元進状態 のパラメーターのひとつとして重要であるが, 一次線溶と二次線溶を鑑別するためには従来用 いられてきた多くの検查法では不充分な点が多 かった. しかし近年 D-dimer 分画が安定化フ ィブリン由来の分解産物であるととを利用して 一次線溶と二次線溶とを鑑別しようとする試み がなされてきだ)5

今回の検討に用いた試薬のモノクローナル抗 体は, 安定化フィブリンから生じるフィブリン 分解産物のうち比較的早期の分画 $(\mathrm{DD} / \mathrm{E}$ complex）に対して反応性が高く後期の分画（late D-dimer) 飞対する反応性は著明に低い特性 を有することが知られておうう ${ }^{677)}$ ，二次線溶の 病態を検討する上で有用と思われた.

臨床検体では DIC 症例の D-dimer 濃度 は, Asserachrom D-Di でカットオフポイン

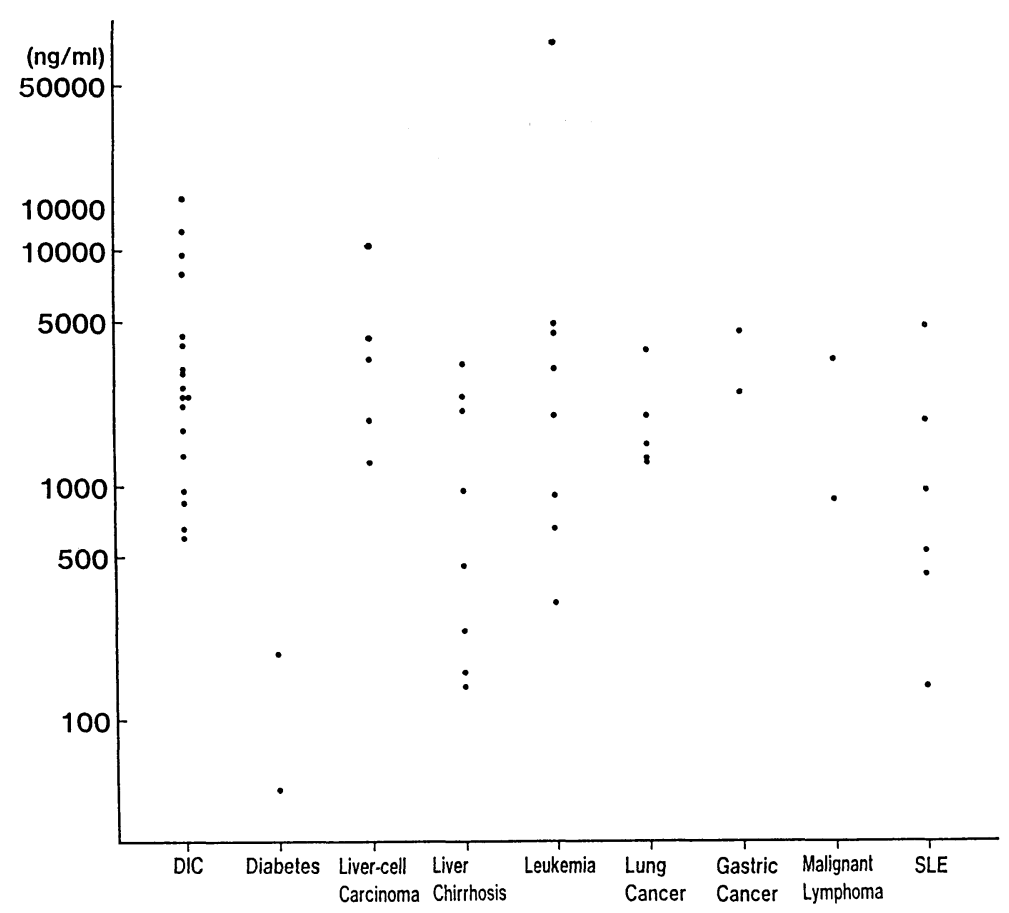

Fig. 5 Plasma D-dimer level in various diseases with Asserachom D-Di 


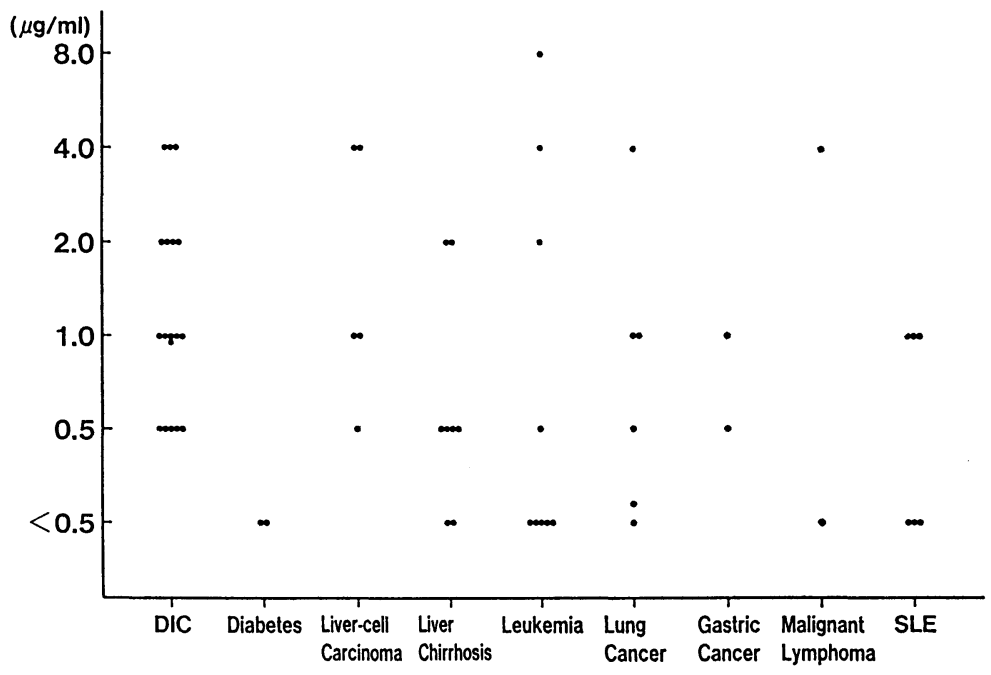

Fig. 6 Plasma D-dimer level in various diseases with D-Di test

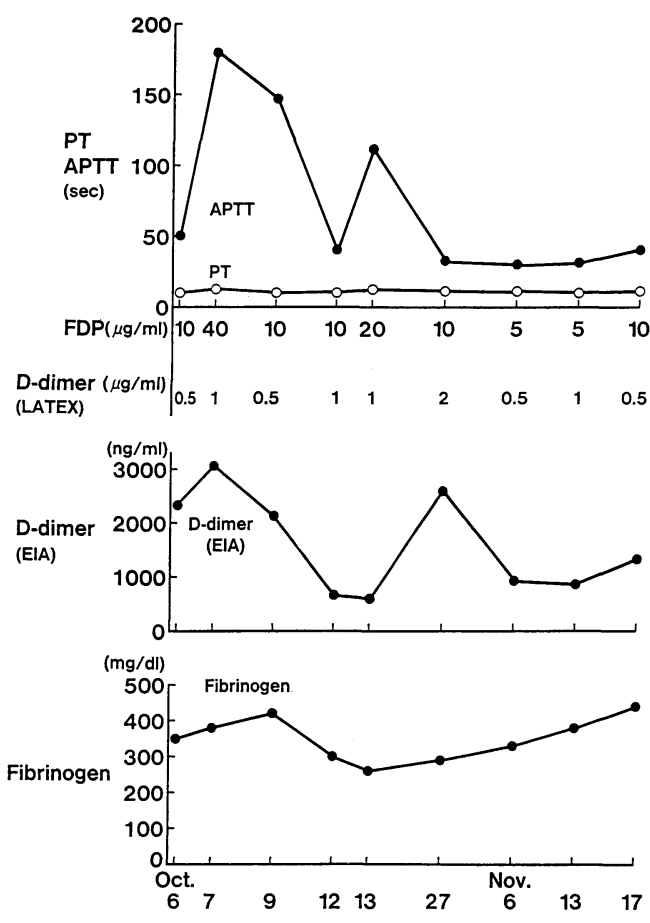

Fig. 7 Changes of hemostatic parameters during the course of DIC in a patient with septicemia

トを $500 \mathrm{ng} / \mathrm{m} l$ とすると特異度 $98.2 \%$, 鋭敏 度 $100 \%$ で DIC 診断に非常に有用であると考 えられた。

D-Di Test ではカットオフポイントを0.5
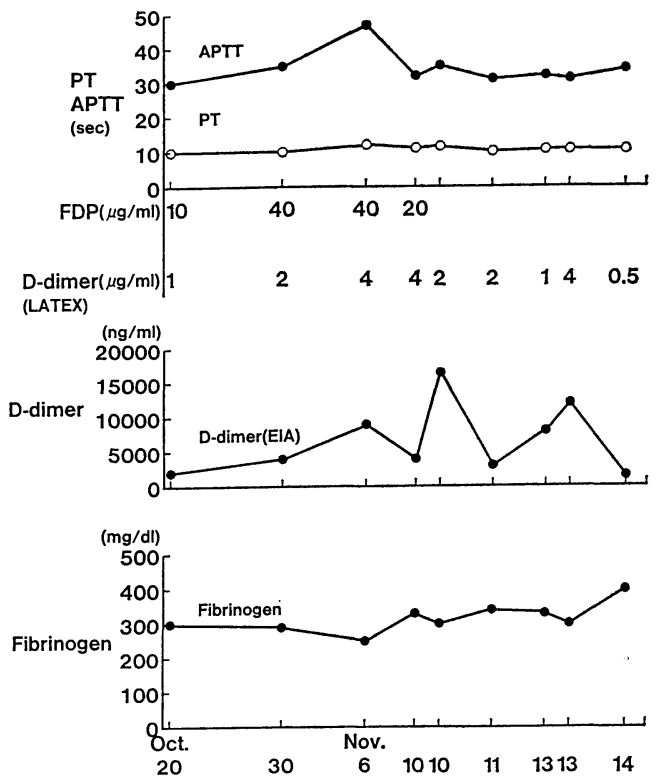

Fig. 8 Changes of hemostatic parameters during the course of DIC in a patint with lung cancer

$\mu \mathrm{g} / \mathrm{m} l$ 以下とした場合特異度 $96.6 \%$ ，鋭敏度 $72.2 \%$ であった。本测定法では D-dimer に 特異性が高いモノクローナル抗体が用いられて おり，EIA 法による D-dimer の測定が高感 度に行えると考え，健常者成人ならびに各種血 栓性疾患々者の血漿検体について検討を行った が，ラテックス凝集法による半定量法の测定值 
とも良好な相関を認めた。本法においては精製 フィブリノゲンとの交差反応性を認めたとの報 告7〕あるが, 従来の FDP 測定法では困難で あった一次線溶と二次線溶との鑑別が本法によ り容易に行えることが推測された。

\section{VI. 結 論}

1）EIA 法を用いた Asserachrom D-Di に よる D-dimer の測定值は Latex 凝集法によ る測定值より定量性の面で優れていることが確 認された。

2）健常者における FDP D-dimer の值は年 齢と共に増加し, 各年代ごとの D-dimer 測定 值は男性よりあ女性において高值を示した。

3）各種血栓性疾患におけるD-dimer の值 は健常者に比較して高値を示した。

4）DIC 症例の臨床経過からその他の各種指 標之良好な相関関係がみられ, 凝固六進状態の 検出の鋭敏な指標之なることが推測された.

以上，モノクローナル抗体を用いた EIA 法 による D-dimer の測定を 500 名の健常者およ び各種血栓性疾患々者の血漿につき検討を行 い，凝固元進状態にともなう線溶六進の指標之 なりうるかどうかの検討を行った.

本法は D-dimer に対して高い特異性を有 し, 従来の FDP 測定法に比較し安定化フィブ リンのプラスミンによる溶解をきわめて早期に 検出できると考えられ，凝固六進状態に括ける 二次線溶の病態の把握に有用な検查法と思われ た。

\section{文献}

1) Qexa, S. A. \& Budzynski, A. Z.: Primary soluble plasmic degradation products of human cross linked fibrin. Isolation and stoichiometry of the (DD) E complex. Biochemistry, 8: 991 995, 1979.

2) Francis, C.W. \& Marder, V.J.: A molecular model of plasmic degradation of cross linked fibrin. Semin. Thromb. Haemost., 8: 25 35, 1982.

3) Mihalyi, E.: Kinetics and molecular mechanism of the proteolytic fragment of fibrin. Ann. N. Y. Acad. Sci., 408: $60 \sim 70$, 1983.

4) 緇荘和子, 他：モノクローナル抗体を用いたラ テックス凝集法による安定化フィブリン分解産 物の検出について. 臨床病理, 33: 1435 1439, 1985.

5) 藤巻道男, 他：モノクローナル抗体を用いた $\mathrm{D}$, $\mathrm{D}-\mathrm{D}$ 分画の測定. 厚生省血液凝固異常症調查研 究班・昭和 59 年業績集報告, 1985, p. 105 110.

6) Amiral, J., et al: Measurement and clinical relevance of D-Dimer by ELISA. Prerented at the Fibrinogen Workshop, Giesen FRG. May 21-24, 1986.

7) 緇荘 和子, 池松 正次郎, 藤巻 道男: ASSERACHROM D-Di による D dimer 分画の定量 測定法の検討. 臨床検査機器·試薬, $10 ： 6$, 1065 1069, 1987. 